
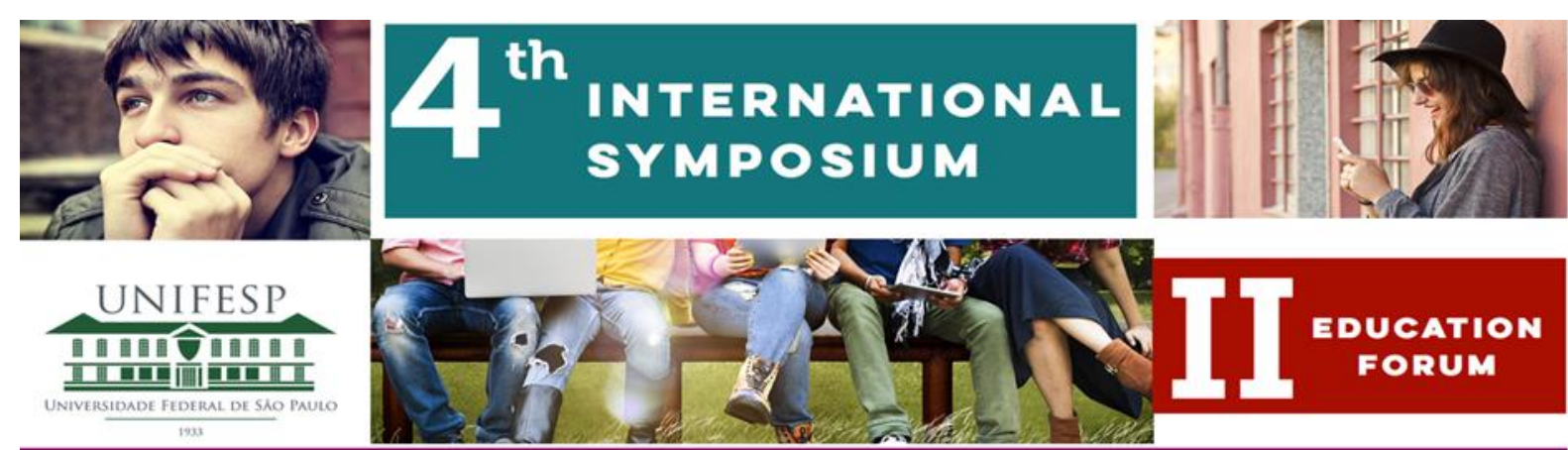

Adolescence(s): Vulnerabilities, Protagonisms and Challenges

\title{
DRUGS VERSUS EDUCATION: A NARRATIVE REVISION OF A GUARULHOS-SP NEIGHBORHOOD BEFORE THE PSYCHO-ACTIVE / PSYCHOTROPIC SUBSTANCES.
}

\author{
DOI: https://doi.org/10.22388/2525-5894.2018.0065
}

David Juglierme Alves Nogueira, ${ }^{1}$ André Luiz Monezi Andrade ${ }^{2}$, Bruno Pinheiro ${ }^{3}$, Erlaine Pinto da Silva Barroso ${ }^{4}$, Denise De Micheli ${ }^{5}$

1. Universidade Federal de São Paulo.david350@hotmail.com

2. Pontifícia Universidade Católica de Campinas. andre.andrade@puc-campinas.edu.br

3. Universidade Federal de São Paulo. pinheiro.bruno10@hotmail.com

4. Universidade Federal de São Paulo. erlainebarroso@gmail.com

5. Universidade Federal de São Paulo. demicheli.unifesp@gmail.com 


\title{
RESUMO
}

Tema geral e problema de pesquisa: A educação tem enfrentado inúmeras intempéries no cotidiano da nação brasileira, especialmente pela influencia de substâncias psicoativas/psicotrópicas e a visão que os adolescentes possuem da escola. O município de Guarulhos-SP, especialmente o bairro do Jardim Acácio, têm vivenciado esse embate diariamente. Objetivo: Descrever as evidências disponíveis da influência do uso de drogas na formação educacional de adolescentes e o impacto desta relação (drogas-educação) no bairro Jardim Acácio na cidade de Guarulhos (SP, Brasil). Métodos: Foi realizada uma busca eletrônica da literatura, busca manual e páginas da web até junho de 2018 para artigos/fontes que cumpriram os critérios de elegibilidade. Resultados: Um total de 22 artigos/fontes foram acessados. O surgimento de bairros sem planejamento, escasso de infraestrutura, carente de serviços e fruto de problemas fundiários, desencadearam numa área com elevado índice de desempregos, uma explosão de crimes e violência. A falta de perspectiva de futuro faz a juventude conviver e adentrar a rota do tráfico eno consequente abandono escolar. Tal reflexão evidenciou a necessidade de reorganizar a região do Jardim Acácio por parte das autoridades governamentais, através do investimento significativo da educação, a construção de escolas, o cuidado ladeado pela dignidade aos professores e responsáveis pelo gerir a educação no âmbito educacional local. Conclusão: Existe uma relação drogas-educação perceptível no bairro do Jardim Acácio, levando a um impacto negativo sobre os adolescentes, desde o abandono escolar e o envolvimento no narcotráfico enquanto viés de um ápice social.

Palavras-Chave: Adolescente. Educação. Dependência química. Violência.

\begin{abstract}
Rationale: Education has faced countless inclemency in the daily life of the Brazilian nation, especially by the influence of psychoactive/psychotropic substances and the adolescents' view of the school. The municipality of Guarulhos-SP, especially the neighborhood of Jardim Acácio, have experienced this daily. Aim: To describe the available evidence of the influence of drug use on the educational background of adolescents and the impact of this relationship (drug-education) in the Jardim Acácio neighborhood in Guarulhos (SP, Brazil). Methods: An electronic literature search, manual search, and web pages were carried out until June 2018 for articles/sources that met the eligibility criteria. Results: A total of 22 articles/sources were accessed. The emergence of unplanned neighborhoods, lack of infrastructure, lack of services and the result of land problems, triggered an area of high unemployment and an explosion of crime and violence. The lack of perspective on the future makes the youth live and enter the route of trafficking and consequent dropout. This reflection evidenced the need to reorganize the region of Jardim Acácio by governmental authorities, through the significant investment of education, the construction of schools, care with dignity for teachers and responsible for managing education in the local educational field. Conclusion: There is a perceptible drugeducation relationship in the neighborhood of Jardim Acácio, leading to a negative impact on adolescents, from school drop-out and involvement in drug trafficking as a social bias.
\end{abstract}

Keywords: Teenager. Education. Chemical dependency. Violence. 


\section{INTRODUCTION}

In recent years, a significant increase has been observed in drug use and drug consumption (Carvalho et al., 2006; Silva et al., 2006; Pasuch \& Oliveira, 2014), as well as the expression of the strength and power of drug trafficking (CASTELLS, 2004; ARBEX JR, 2005; FEFFERMAN, 2006; ROCHA, 2012). This reality constitutes a social and health problem in many nations, including Brazil (GALDURÓZ, 1997; ESPUNY, 2010). As a burden, drug consumption has consequences on individuals' emotional and physical development (ESPUNY, 2010), in addition to interference in brain maturation, whose reflection can be ascertained in cognitive and emotional changes (NASCIMENTO \& DE MICHELI, 2014).

The use of illicit substances and the force of drug trafficking have been reported in the adolescent population at an early stage (WHO, 2003). One of the first consequences of the use of psychoactive substances and involvement with drug trafficking is school dropout (PATTO, 1997), destruction of the individual's health as a product of dependence (GALDURÓZ, 1997) and the increase in the rate of violence (WHO, 2003). In such contexts, school failure flourishes and entails many implications (ZAMORA, 2008), from the formation of identity, family transition, the social and economic role of the adolescent, an environment conducive to social segregation until the deprivation of the essential rights to the individual and their human experience. Low schooling creates a preponderant social exclusion, which generates a transitional crisis in the adolescent's life, passing through paradoxes, aggressiveness, intrepidity, at the same time, drowsiness, deep dissatisfaction with one's own life and procrastination in decision making (PATTO, 1997).

Several risk factors encompass the adolescent before drugs (ROCHA, 2012). From the involvement of family members in drug use, family conflicts, rejection in the school environment, proximity to friends who use drugs, curiosity about drug use, social precariousness, favorable social environment and easy access to drugs, among others (HAWKINS; CATALANO; MILLER, 2017). Only in crime do children under 18 have almost equal employment opportunities, even when compared to adults. (OIT, 2002).

In the state of São Paulo, similar problems occur in the city of Guarulhos, especially in the Jardim Acácio neighborhood located in the region of Taboão (Revista 
Maromomi DIGITAL, 2017), an area with enormous geographical and population density within the municipality of Guarulhos (AAPAH, 2017).

Therefore, the purpose of this narrative review is to describe the available evidence on the influence of the use of psychotropic substances on the educational background of adolescents and the impact of this relationship (drugs-education) in the Jardim Acácio neighborhood in the city of Guarulhos (SP, Brazil).

\section{METHOD}

A narrative review of the literature was conducted with the purpose of answering the following research question: What is the influence of drug use on the educational background of adolescents in the Jardim Acácio neighborhood in the city of Guarulhos (SP, Brazil)?

\section{Inclusion Criteria}

The publications that met the following criteria were included: studies with an experimental design, published between 2007-2017 (since the research was delimited within the scope of a decade), publications that highlighted the reality of the city of Guarulhos ( SP, Brazil) and its context, be it violence, education and social development, and which emphasize the role of psychoactive substances in the life of adolescents and their reflection in the perspective of their future.

\section{Exclusion Criteria}

Publications based on the following criteria were excluded: literature reviews, studies that did not have a connection with the city of Guarulhos (SP, Brazil), or even their social context, and studies that came from countries or reality different from those found in region of the Jardim Acácio neighborhood (Guarulhos, SP, Brazil). 


\section{Search strategy}

The databases/sources LILACS, Scielo, Google Academic and CAPES, were searched between February and June of 2018 by three independent reviewers (NOGUEIRA, PINHEIRO and DE MICHELI). The search strategy included the following keywords: "Adolescent," "Education," "Substance-Related Disorders," "Drug Demand Behavior," "Violence." As a compliment, cross-referencing was bibliographical references for each article/ sites/journals retrieved in order to include studies/sources that were outside the previously defined strategy. The publications were selected by three independent researchers (NOGUEIRA, PINHEIRO and DE MICHELI). After deleting the duplicates, the titles and abstracts were examined. Any disagreement was resolved through the scientific discussion of the researchers until a consensus was reached. The studies that met the inclusion and exclusion criteria were processed for data extraction, performed by three independent researchers (NOGUEIRA, PINHEIRO and DE MICHELI).

\section{RESULT}

A total of 23 articles/sources were accessed in the present narrative review. The selected and analyzed publications are described in Table 1. Table 2 presents the main information from the selected publications. Of the total, 12 articles, five books (available online), four magazines and one informative video about the municipality of Guarulhos.

Table 1. Title and year of publication of the selected publications and platforms accessed.

\begin{tabular}{c|c|c}
\hline TITLES & Years & DATABASES \\
\hline $\begin{array}{c}\text { Risk and protective factors for alcohol and other drug problems in adolescence and } \\
\text { early adulthood: implications for substance abuse prevention. }\end{array}$ & 1992 & $\begin{array}{c}\text { Lilacs / } \\
\text { PubMed }\end{array}$ \\
\hline $\begin{array}{c}\text { IV Survey on the Use of Drugs among Students of first and 2nd grades in 10 } \\
\text { Brazilian Capitals. }\end{array}$ & 1997 & ADOLEC \\
\hline Children in drug trafficking: a quick diagnosis & 2002 & $\begin{array}{c}\text { Google } \\
\text { Acadêmico }\end{array}$ \\
\hline Disorders due to the use of substances. & 2003 & Scielo \\
\hline $\begin{array}{c}\text { Profile of adolescents in conflict with the law represented by the Office of the } \\
\text { Prosecutor of Justice for Children and Adolescents in Salvador (2000-2003). }\end{array}$ & 2005 & Scielo \\
\hline
\end{tabular}




\begin{tabular}{|c|c|c|}
\hline $\begin{array}{l}\text { II Household survey on the use of psychotropic drugs in Brazil: a study involving the } \\
108 \text { largest cities in the country. }\end{array}$ & 2005 & Scielo \\
\hline $\begin{array}{l}\text { Adolescents in Conflict with the Law: A Brief Examination of Recent Production in } \\
\text { Psychology. }\end{array}$ & 2008 & Scielo \\
\hline Identity formation: a perspective of articulation with work in adolescence. & 2011 & CAPES \\
\hline Adolescents, socio-educational measures and work & 2011 & Scielo \\
\hline Patrimonial Education & 2012 & Scielo \\
\hline Brazilian report on drugs / National Secretariat for Policy on Drugs & 2009 & $\begin{array}{c}\text { Google } \\
\text { Acadêmico }\end{array}$ \\
\hline $\begin{array}{c}\text { Vulnerabilities in childhood and adolescence and Brazilian public intervention } \\
\text { policies }\end{array}$ & 2013 & Scielo \\
\hline $\begin{array}{c}\text { Evaluation of different modalities of preventive actions in reducing the consumption } \\
\text { of psychotropic substances in students in the school environment: a randomized } \\
\text { study. }\end{array}$ & 2014 & Scielo \\
\hline Survey on Drug Use by High School Students: A Systematic Review. & 2014 & Scielo \\
\hline Guarulhos: "what city life cycle we are in" & 2015 & Scielo \\
\hline $\begin{array}{l}\text { Prevention to the abusive consumption of drugs in the school: challenges and } \\
\text { possibilities for the educator's action. }\end{array}$ & 2015 & Scielo \\
\hline Many cities in one! & 2017 & Scielo \\
\hline $\begin{array}{l}\text { In the district where there are more deaths in the megacity of SP, police station } \\
\text { closes on Friday and only opens on Monday. }\end{array}$ & 2017 & Scielo \\
\hline Historical, cultural guide of Guarulhos's places and memories. & 2017 & Scielo \\
\hline Program on Taboão. & 2017 & Scielo \\
\hline Guarulhos: Panorama & 2018 & Scielo \\
\hline Economy of Guarulhos & 2018 & Scielo \\
\hline
\end{tabular}

The neighborhood of Jardim Acácio has some peculiarities, such as the lack of a public leisure area, a high school (AAPAH, 2017), pharmacies, butchers, etc. In Edgar Morin's (2011, page 13) understanding of education, "it is fundamental to create dialogic, creative, reflective and democratic spaces capable of doing pedagogical practices based on solidarity, ethics, peace, and social justice."

Faced with the increase in drug use and the search for combat actions and youth awareness, "school has been considered a privileged space for these actions" (MOREIRA, VIO, MICHELI, 2015, p 121).

However, in parallel with the frank development of the Jardim Acácio neighborhood, drug trafficking (ESPUNY, 2010) has emerged with great force, especially in recruiting adolescents for affordable labor and the simulation of a possible financial apex (AAPAH, 2017).

The 9th Police District of Guarulhos covers the neighborhood of Jardim Acácio. Regarding violence, the picture is alarming, because it is the "the district with more 
deaths in the megacity of SP, and the police station closes on Friday and only opens Monday" (SILVA, 2017). The picture is worrying, "in 2017, was not killed anywhere else in the metropolitan region as in the Taboão region. Wholesale killings, barbaric killings, and crimes of passion make up the statistics of the 33 illegal killings until May in a region of 130,000 inhabitants "(SILVA, 2017).

This reality was preponderant for the increase of the numbers of the violence and consequent negative repercussion. "Looking back over the years of this decade (2007-2017), we never had that many murders. Last year, there were 27 killed in the neighborhood. In the year with the most records, in 2012, there were 36 deaths in 12 months until May of that year. However, ten homicides had been registered in the region "(SILVA, 2017). This high rate of violence increases continuously and influences social development (ROCHA, 2012). "However, it is the production of public policies aimed at the target group, which would include activities aimed at increasing citizenship and integrated policies" (OTI, 2002, p.75).

The Jardim Acácio, as well as the city of Guarulhos itself "advanced without planning of its whole; deployment of lots, without infrastructure, without services; favelas in the green areas and institutional areas of allotments "(INSTITUTO VISÃO PÚBLICA, 2015).

The secretary of public security in the municipality of Guarulhos lists the reasons for such violence and death in the Taboão region and its surroundings: land problems (invasion of housing), flow of migrants from other states, trafficking, as a route of work and income, especially for the young, and lack of education (SILVA, 2017). "As a comparison, the police station with the most intentional homicides in São Paulo, the 73rd DP, in Jaçanã (northern area), recorded 16 homicides, less than half of those in Taboão" (SILVA, 2017).

There is an interweaving between the abandonment of public policies, the scarcity of social options for the population, childhood/adolescence regrouped by the power of drugs, increased influence of narcotics, increased violence and mortality.

Currently, the data are from the 9th DP and the municipality of Guarulhos, a higher incidence of documented academic research of this reality has not been found, which implies a later deepening in order to elucidate this reality. 
Table 2. Main results of selected publications.

\begin{tabular}{|c|c|}
\hline REFERENCE & MAIN RESULTS \\
\hline $\begin{array}{l}\text { Hawkins, } \\
\text { Catalano } \\
\text { \&Miller (1992) }\end{array}$ & $\begin{array}{l}\text { Seek to identify risk factors for alcohol and other drug dependence in adolescence } \\
\text { through a risk factor approach. These factors include vulnerability, domestic } \\
\text { violence, peer pressure, conflicts in the relationship with parents, search for a social } \\
\text { apex, among others. }\end{array}$ \\
\hline $\begin{array}{l}\text { Galduróz, } \\
\text { Noto \&Carlini } \\
\text { (1997) }\end{array}$ & $\begin{array}{l}\text { The increase of drugs among Brazilian students between 1st and 2nd grades. The } \\
\text { data indicate that adolescence is a period of fragility in the face of substance use. It } \\
\text { is also a phase of early exposure to the psychoactive substances blooming in an } \\
\text { unreasonable use and this tied in a large extent to curiosity. }\end{array}$ \\
\hline Carlini (2002) & $\begin{array}{l}\text { In coordinating a national survey on drug use in Brazil, the prevalence of illicit use } \\
\text { of drugs, alcohol, anabolic steroids, and tobacco and the misuse of psychotropic } \\
\text { drugs commonly without a medical prescription is predominant. Moreover, this } \\
\text { reflects negatively on the structure of society, increased violence, cultural and } \\
\text { economic losses, decreased productivity of industry since workers are affected by } \\
\text { chemical dependency and its effects on social every day. } \\
\text { It is worth highlighting the growth in licit drug consumption in the country, especially } \\
\text { alcohol and tobacco, reaching over } 11 \% \text { and } 9 \% \text { of dependents, respectively. }\end{array}$ \\
\hline $\begin{array}{l}\text { Organização } \\
\text { Nacional do } \\
\text { Trabalho - } \\
\text { OIT (2002) }\end{array}$ & $\begin{array}{l}\text { The discussion involves the involvement of children and adolescents in daily drug } \\
\text { trafficking, especially in communities in Rio de Janeiro (RJ, Brazil). The survey } \\
\text { shows an increase in contraventions and a reduction in the age of entry into drug } \\
\text { trafficking, making it an increasingly young group at the frontiers of illicit involvement. } \\
\text { Characterized by poverty in the home, dropping out of school, a means of acquiring } \\
\text { prestige in the community, access to resources and consumer goods that they might } \\
\text { not otherwise be able to acquire, being their convivial environment and friendships } \\
\text { restricted to those involved in drug trafficking. Moreover, the constant fear of arrest, } \\
\text { death or betrayal of the group members. }\end{array}$ \\
\hline $\begin{array}{l}\text { Organização } \\
\text { Mundial da } \\
\text { Saúde - OMS } \\
(2003)\end{array}$ & $\begin{array}{l}\text { It lists the disorders due to the use of anabolic substances, tobacco, hallucinogens, } \\
\text { opiates, cannabis, alcohol, caffeine, anxiolytic/sedative medication, solvents and } \\
\text { stimulants/amphetamines. These substances affect the brain system, resulting in } \\
\text { feelings of pleasure, on the other hand, causes disorder as it stimulates the desire } \\
\text { to consume more substances. In the search for accomplishing the desire, they } \\
\text { abandon their day-to-day activities to the detriment of substance use. }\end{array}$ \\
\hline $\begin{array}{l}\text { Tapparelli } \\
\text { \&Almeida } \\
\text { (2005) }\end{array}$ & $\begin{array}{l}\text { When examining the problem of juvenile offenses in the city of Salvador (BA, Brazil) } \\
\text { between } 2000 \text { and } 2003 \text {, mentions that this is a specificity of the collective } \\
\text { imagination and fed by mediatic approaches. This corroborates the reinforcement } \\
\text { of insecurity in the social interaction with adolescents in conflict with the criminal } \\
\text { law, so repression becomes an element of social construction. }\end{array}$ \\
\hline $\begin{array}{c}\text { Zamora } \\
\text { (2008) }\end{array}$ & $\begin{array}{l}\text { It presents briefly, a series of works between } 2001-2007 \text { in the area of psychology } \\
\text { dealing with adolescents in conflict with the law. In doing so, there is a common bias } \\
\text { among the researches, from the motivations that caused the crime committed by } \\
\text { adolescents, family/community relationship, the role of illicit substances in the } \\
\text { context of life, the reality modus operandi of Brazil's socio-educational system. }\end{array}$ \\
\hline Alvarez (2011) & $\begin{array}{l}\text { It enters the process of building the identity of adolescents in the labor market and } \\
\text { for this, makes its "Young Apprentice Program" considerations from the theoretical } \\
\text { reference of socio-historical psychology, especially when identifying the social } \\
\text { reality of the participants and the motivations of early entry into the labor market, } \\
\text { which is also the incentive of social stratification. }\end{array}$ \\
\hline $\begin{array}{c}\text { Andrade } \\
\text { (2009) }\end{array}$ & $\begin{array}{l}\text { Describes that the invitation to the work of drug trafficking is also an invitation to } \\
\text { recognition and to enter the world of consumption. If, on the one hand, the } \\
\text { adolescents in conflict generally do not have a regular job, on the other hand, drug } \\
\text { trafficking with its peculiarities and risks adds. }\end{array}$ \\
\hline $\begin{array}{l}\text { Revista de } \\
\text { Educação } \\
\text { (2012) }\end{array}$ & $\begin{array}{l}\text { It describes part of the history, culture, and environment of the municipality of } \\
\text { Guarulhos (SP, Brazil), with its peculiarities, histories and social factors that } \\
\text { contributed to the formation, identity, and development of the people of Guarulhos. }\end{array}$ \\
\hline
\end{tabular}




\begin{tabular}{|c|c|}
\hline & $\begin{array}{l}\text { The influence of cultures and ethnicities in the formation of local society, of the habits } \\
\text { and folklore of the city. The edition is part of the curricular proposal of the } \\
\text { municipality in 2012, called "Required Knowledge Framework (QSN)," }\end{array}$ \\
\hline $\begin{array}{l}\text { Brazilian } \\
\text { report on } \\
\text { drugs of the } \\
\text { National } \\
\text { Secretariat of } \\
\text { Policy on } \\
\text { Drugs SENAD } \\
\text { / Brazil (Brazil, } \\
\text { 2009) }\end{array}$ & $\begin{array}{l}\text { Resulted in an accurate survey of data between the years } 2001-2007 \text { that offers a } \\
\text { panoramic view of the distribution, traffic, consumption, and impact of psychoactive } \\
\text { substances in Brazilian society. It is a basic document that offered characteristics of } \\
\text { the Brazilian reality in the confrontation of licit and illicit substances at state and } \\
\text { national level, as well as describe the situation of this cause in Brazilian capitals. }\end{array}$ \\
\hline $\begin{array}{c}\text { Fonseca } \\
(2013)\end{array}$ & $\begin{array}{l}\text { When reviewing and discussing vulnerabilities in childhood and adolescence and } \\
\text { the Brazilian public policies of intervention propose a narrative review between } \\
1990-2012 \text {, based on the database of the Virtual Health Library - VHL. Vulnerability } \\
\text { manifests itself in the most varied forms, both in the family and school context, } \\
\text { advocating that children and adolescents suffer situations of violence, degradation } \\
\text { of the human figure, exploitation and slavery, physical, emotional and affecting their } \\
\text { health. }\end{array}$ \\
\hline $\begin{array}{l}\text { Nascimento } \\
\text { \&De Micheli } \\
\quad(2014)\end{array}$ & $\begin{array}{l}\text { When evaluating the preventive actions of the consumption of psychotropic } \\
\text { substances in students in the school environment, they emphasize that although } \\
\text { some schools develop preventive actions in the use of drugs, the practical results } \\
\text { are usually unknown. A total of more than } 1,300 \text { students from the state public } \\
\text { network of the city of Guarulhos (SP, Brazil) participated in the study between the } \\
9 \text { th year of primary education and the 3rd year of secondary education. The } \\
\text { researchers observed a reduction of the consumption of the psychotropic } \\
\text { substances, from the interventions made by the educators, especially, through } \\
\text { contextualized actions the reality of the student and the school. }\end{array}$ \\
\hline $\begin{array}{l}\text { Pasuch } \\
\text { \&Oliveira } \\
(2014)\end{array}$ & $\begin{array}{l}\text { From a systematic review, they survey the use of psychoactive substances by high } \\
\text { school students. Adolescents have their first experiences with licit substances } \\
\text { through alcohol and tobacco, and this from familiar environments, which } \\
\text { demonstrates that exposure and vulnerability to substance use reach this group } \\
\text { expressively. }\end{array}$ \\
\hline $\begin{array}{l}\text { Instituto Visão } \\
\text { Pública (2015) }\end{array}$ & $\begin{array}{l}\text { An analysis of the real situation of the city of Guarulhos (SP, Brazil), from a question: } \\
\text { in which cycle of the life of the city we are? It is made a historical description of the } \\
\text { city that underwent structural changes, which implies the need to see the city } \\
\text { differently. }\end{array}$ \\
\hline $\begin{array}{l}\text { Moreira, Vóvio } \\
\text { \&De Micheli } \\
\text { (2015) }\end{array}$ & $\begin{array}{l}\text { Deal with the prevention of drug abuse at school, the concern of society and a } \\
\text { challenge to education and health professionals. To elucidate the role of education } \\
\text { the researchers delimited the research from primary school teachers II, working in } \\
\text { two public schools in the city of São Paulo, for this they used focus groups, } \\
\text { questionnaire and training meetings. }\end{array}$ \\
\hline $\begin{array}{c}\text { Revista } \\
\text { Maromomi } \\
\text { Digital (2017) }\end{array}$ & $\begin{array}{l}\text { It commemorates the origins, formation, and itinerary that the city of Guarulhos (SP, } \\
\text { Brazil) ran from its foundation to become the } 2 \text { nd most populated city in the state of } \\
\text { São Paulo, to have the 14th largest gross domestic product in Brazil and to own the } \\
\text { 53rd most populous in the American continent. }\end{array}$ \\
\hline Silva (2017) & $\begin{array}{l}\text { Describes the dark reality that hangs in the city of Guarulhos, owns the most violent } \\
\text { police department of the São Paulo megacity. It is the place where there are more } \\
\text { deaths, murders, and crimes of passion. Outstanding detail, the police station runs } \\
\text { until Friday and only reopens on Monday. The 9th DP is located in the region of } \\
\text { Taboão whose population is estimated at } 130 \text { thousand inhabitants, which } \\
\text { encompasses the neighborhood of Jardim Acácio. }\end{array}$ \\
\hline $\begin{array}{l}\text { Associação } \\
\text { Amigos do } \\
\text { Patrimônio e } \\
\text { Arquivo } \\
\text { Histórico- } \\
\text { AAPAH } \\
\text { (2017a) }\end{array}$ & $\begin{array}{l}\text { It presents a historical, cultural guide of places and memories of Guarulhos (SP, } \\
\text { Brazil). Underlining the changes, mutations, and development of the city, besides } \\
\text { the historical singularities, the idea is to foment the desire on the part of the } \\
\text { inhabitants in search of the knowledge and preservation of the cultural history. }\end{array}$ \\
\hline
\end{tabular}




\begin{tabular}{|c|c|}
\hline $\begin{array}{l}\text { AAPAH } \\
(2017 \mathrm{~b})\end{array}$ & $\begin{array}{l}\text { It makes a description related to the Taboão region, its beginnings, development, } \\
\text { unplanned growth, the advent and establishment of diversified commerce, besides } \\
\text { the population increase flourishing in the emergence of numerous neighborhoods } \\
\text { within the Taboão region and its surroundings. }\end{array}$ \\
\hline $\begin{array}{l}\text { Instituto } \\
\text { Brasileiro de } \\
\text { Geografia e } \\
\text { Estatística- } \\
\text { IBGE (2018) }\end{array}$ & $\begin{array}{l}\text { Describes an overview of the municipality of Guarulhos with its population strength, } \\
\text { its industrial advance, extensions of areas with potential for growth and expansion. }\end{array}$ \\
\hline $\begin{array}{c}\text { Prefeitura de } \\
\text { Guarulhos } \\
(2018)\end{array}$ & $\begin{array}{l}\text { Describes an overview of the municipality of Guarulhos with its population strength, } \\
\text { its industrial advance, extensions of areas with potential for growth and expansion. } \\
\text { It highlights the economy of the municipality and the strength of gross domestic } \\
\text { product (GDP), a fact that gives prominence to the city, attracting new ventures and } \\
\text { the emergence of new companies. In addition to its constant population growth, } \\
\text { moving the city and the daily life of the inhabitants. }\end{array}$ \\
\hline
\end{tabular}

\section{DISCUSSION}

This is the first literature / integrative narrative review to evaluate the influence of drug use on the educational background of adolescents and the impact of this relationship (drug-education) in the Jardim Acácio neighborhood of the city of Guarulhos (SP, Brazil). The results indicate that violence has erupted significantly in the last ten years, being the region with the highest death rate in the state of São Paulo in 2017. The high consumption of psychoactive drugs and the drug trade have taken root, greater number of people are getting involved, as a result of abandonment and forgetfulness of the government through public policies, investments in leisure and education, scrapped schools and children and adolescents harassed by the traffic bias presented as a tool of social scale.

In this way, "the particular history of drugs illuminates the general history of humanity with its light, as when we open the window until then closed by the horizon, and the same things appear from a new perspective" (ESCOHOTADO, 2004, p.7). Therefore, "to know the human is, first of all, to situate him in the universe, and not to separate him from the world ..." (Morin, 2011, 16). -17).

In this context of vulnerability, the clash between education and drug trafficking becomes present and perceptible (MARTINS \& PAGNAN, 2011). The drug trade inside the school, in its surroundings and the communities gains projection and a greater reach continuously (ESPUNY, 2010).

A survey carried out by the International Labor Organization (ILO, 2002) reports that one of the causes that trafficking uses for the rampant search for adolescents involves the reduction of labor costs and a shorter time in prison in case of a seizure. 
What arouses the interest by this profile of workers, transforming many even, in support of the family. "The use of minors in the activity keeps costs lower than if adults participated in their place, particularly when prisons occur" (ILO, 2002, p. Thus, "since the time of imprisonment of minors is shorter, support for the" inactive "worker demands a lower cost" (ILO, 2002, p. Therefore, "it is important to note, however, that what the data suggest, and several researchers confirm, is that the age of the children employed by the drug trade is declining" (ILO, 2002, 45).

The importance of seeking to understand the identity of adolescents involved in trafficking, as part of their construction and individuals who establish social relations throughout life and within the social model in which they live (RODRIGUES; ASSMAR; JABLONSKY, 2005). In this context the drug-trafficking environment becomes "a symbol of power and possessions, they represent an important form of distinction" (BOURDIEU apud ILO, 2002, p.35). In this way, "the illusion of consumption gives these adolescents a sense of strength; have something that social inequality, intrinsic to Brazilian society, limits "(BOURDIEU apud ILO, 2002, p.35), and the danger that lies in the world of drugs, becomes compensatory, as a social place (PASUCH, OLIVEIRA, 2014 ). "It is so important and rewarding for them to enter a clothing store in a shopping mall, choose the clothes they like best, try them on and buy them, that the risks of working in drug trafficking are justified" (MOREIRA, 2000, p. 109). School dropout rate (PATTO, 1997), together with the proposals made by the environment of drug trafficking (ROCHA, 2012), it frightens and corroborates the distancing of these adolescents from school.

The involvement of adolescents in drug trafficking and drug use leads to terrible consequences, including social stigma (ESPUNY, 2010). Parallel to this, trafficking becomes, in the perspective of the adolescent, a way out of the social ascension and fulfillment of the desires of the consumer society (BAUMAN, 1998). Thus, trafficking sells the yearning to be an active participant of the consumer society.

In this social gap, drug trafficking is gaining ground, is considered a new illicit market (SANTOS, 2005). Enlisting teenagers as "drug traffickers. Workers who are involved in a contradictory game involving the criminalization of poverty, risks, momentary satisfaction and exploitation of the workforce "(ROCHA, 2012, p.5).

However, in addition to reducing the accessibility of drugs, education can foster healthy activities that lead to relationships (DE MICHELI; FORMIGIONI, 2002) among 
friends, parents, and educators, thus making it possible to face the harsh reality of drug trafficking. The increase in drug use and involvement with drug trafficking in adolescence lead to school failure, even altering the perspective of citizenship on the part of these youths, as the route of trafficking becomes attractive and, at the same time, a path of social escalation.

Observing the environment flanked by psychoactive/psychotropic substances, adolescence, schooling and prospects for youth, becomes a challenging task. We can see the change in the life stage between childhood and adolescence of the so-called "scouts," "small planes" and "soldiers" of the trafficking, which allows access to them and their respective families (ZAMORA, 2008; ROCHA, 2012).

In the peripheral region (ROCHA, 2012) there is a fine line between the ideology of education (PATTO, 1997) and the strong influence and enticement of trafficking in adolescents' lives (ZAMORA, 2008). This is corroborated by the restricted access to public policies aimed at addressing social ills (SANTOS, 2005) and consequently the institutionalization of vulnerability (FONSECA et al., 2013). Thus, it is necessary to investigate the picture of an environment flanked by trafficking (ROCHA, 2012), based on the vision and perception of adolescents directly involved in drug trafficking. "In certain situations, the state of vulnerability can affect health, even in the absence of disease, but with the psychological, social or mental state of children and adolescents" (FONSECA et al., 2013, p.259).

Between the years 2007-2017 was the period of contrasts in the note of Ideb, an elementary school of the State School Mayor Rinaldo Poli. On the one hand, the small evolution in the "Initial Years (6th and 7th year): learning 6.59 - the higher the grade, the greater the learning. Flow 1.00 - the higher the value, the greater the approval. Ideb 6,6 - Goal for school 5.8 "(QEDU, 2017). On the other hand, it has been the period of mishaps in the "Final Years (8th and 9th year): learning 4.93 - the higher the grade, the greater the learning. Flow 0.98 - the higher the value, the greater the approval. Ideb 4.8 - Goal for school 5.1 "(QEDU, 2017).

The index in the final years includes adolescents between 12 and 14 years of age, an essential phase in the formation and development of future perspectives. Studies point to changes in the knowable aspects of adolescents involved in drug use (NASH, MICHELI, 2014) and this may reflect in numerous mismatches (ESPUNY, 2010), including in school failure (PATTO, 1997). We can not fail to mention that almost 
nine out of ten adolescents in the so-called socio-educational system in Brazil were drugged when they committed the infractions (ZAMORA, 2008).

It is perceptible from the issues raised here, the interconnection between education, society, and health in the face of adversity, expressed in the school environment flanked by trafficking. Traffic grooming corroborates school failure (PATTO, 1997; ZAMORA, 2008) and contributes to the validation of vulnerabilities.

This study brought to light the most violent region of the state of São Paulo according to the last data described by the state government in 2017 , which made it possible to highlight the peculiarities of the Taboão region, in the city of Guarulhos (SP, Brazil), especially the neighborhood of Jardim Acácio. On the other hand, the limitations of this study lie in the fact that an incidence of documented academic research of this reality was not found. The researchers must develop future research with a deepening of these points in order to clarify such peculiarities.

\section{FINAL CONSIDERATIONS}

This review sought to understand the intricacies of education in the context of social vulnerability, expressed in particular by trafficking, the abandonment of public policies and the consequent increase in crime. The role that the school and its educational practice can play in coping with deplorable situations, whose children and adolescents are victimized and excluded from a praxis of human dignity, has become perceptive.

The neighborhood of Jardim Acácio, located in the region of Taboão in the city of Guarulhos-SP, coexists with a deficit housing structure, as a result of unplanned growth by the public power, increased violence expressed by the police department (9th DP) more of the state of São Paulo reflected in the critical note of Ideb referring to the final years of elementary school. This reflection evidenced the need to reorganize the region on the part of the governmental authorities, ranging from the valorization of education, the care with dignity to the teachers and those responsible for managing education in the local educational sphere, the construction of schools and social spaces for the and the construction of a citizenship that expresses the dignity of the human subject, with access to the basic needs served, from education, sanitation, housing, security and health. 
The drug-education relationship was noticeable in the course of the study. The increase in drug use and involvement with drug trafficking in adolescence lead to school failure, even altering the perspective of citizenship on the part of these youths, as the route of trafficking becomes attractive and, at the same time, a path of social escalation.

\section{REFERENCES}

AAPAH - Associação Amigos do Patrimônio e Arquivo Histórico. Guia histórico cultural de logradores, lugares e memórias de Guarulhos. Guarulhos, 2017a. Disponível em: $<$ http://aapah.org.br/2015/03/18/guia-historico-cultural-de-logradouros-lugares-ememorias-de-guarulhos/>. Acesso em: 15 ago. 2017.

AAPAH - Associação Amigos do Patrimônio e Arquivo Histórico. Programa sobre o Taboão. Guarulhos, 2017b.Disponível em: <http://aapah.org.br/2017/03/24/assista-o-programasobre-o-taboao/>. Acesso em: 10 ago. 2017.

ALVAREZ, Patricia Elizabeth Sanz [et al.].Formação da Identidade: uma perspectiva de articulação com o trabalho na adolescência.2011. CARPE DIEM: Revista Cultural e Científica da FACEX, v. 9, n. 9 (2011). Natal: 2011.

ANDRADE, Marcela Silva. Os adolescentes, medidas socioeducativas e trabalho.XIII Colóquio Internacional de Psicossociologia e Sociologia Clínica. UFMG, Belo Horizonte, 04 a 07 de agosto de 2009. Disponível em: <http://www.fafich.ufmg.br/coloquioenriquez/tcompletos/184/texto\%20coloquio\%20comple to.pdf>. Acesso em: $10 \mathrm{dez} .2016$.

ARBEX JR, José. Narcotráfico: um jogo de poder nas Américas. Editora Moderna. 2005. São Paulo.

BAUMAN, Zygmunt. O mal-estar da pós-modernidade. Rio de Janeiro: Jorge Zahar Ed., 1998.

BRASIL. Constituição (1988). Constituição da República Federativa do Brasil. 40 ed. São Paulo: Saraiva, 2007.

BRASIL. Presidência da República. Secretaria Nacional de Políticas sobre Drogas. Relatório brasileiro sobre drogas / Secretaria Nacional de Políticas sobre Drogas; IME USP; organizadores Paulina do Carmo Arruda Vieira Duarte, Vladimir de Andrade Stempliuk e Lúcia Pereira Barroso. - Brasília: SENAD, 2009.

CARLINI, Elisaldo Araujo (supervisão) [et al.]. II Levantamento domiciliar sobre o uso de drogas psicotrópicas no Brasil: estudo envolvendo as 108 maiores cidades do país. 2005. São Paulo: CEBRID - Centro Brasileiro de Informações Sobre Drogas Psicotrópicas: UNIFESP - Universidade Federal de São Paulo, 2006.

CASTELLS, Manuel. Fim do Milênio - a era da Informação: economia, sociedade e cultura. Vol. 3. São Paulo. Editora Paz e Terra, 2004. 
DE MICHELI; Denise; FORMIGONI, Maria Lucia Oliveira Souza. Are reasons for the first use drugs and family circumstances predictors of future our patterns? AddictiveBehaviors - $v$. 27, n. 1, p. 87-100, 2002.

ESCOHOTADO, Antônio. História elementar das drogas. Lisboa: Antígona, 2004.

ESCOL.AS. Rinaldo Poli Prefeito: Escola Pública Estadual. 2016. Disponível em: <http://www.escol.as/221169-rinaldo-poli-prefeito>. Acesso em: 12 jul. 2017.

ESPUNY, Herbert Gonçalves. Narcotraficância e os adolescentes em conflito com a lei. Dissertação (Mestrado Profissional em Políticas e Práticas com Adolescentes em Conflito com a Lei). Universidade Bandeirante. São Paulo, 2010.

FEFFERMAN, Marisa. Vidas arriscadas: o cotidiano dos jovens trabalhadores do tráfico. Petrópolis: Vozes, 2006.

FONSECA, F. F., SENA, R. K. R., SANTOS, R. L. A., DIAS, O. V., \& COSTA, S. M. As vulnerabilidades na infância e adolescência e as políticas públicas brasileiras de intervenção. Revista Paulista de Pediatria.V. 31, p. 258-264. São Paulo: Scielo, 2013.

GALDURÓZ, José Carlos F. [et al.]; NOTO, A. R.; CARLINI, E. A. IV Levantamento sobre o Uso de Drogas entre Estudantes de $1^{\circ}$ e $2^{\circ}$ graus em 10 Capitais Brasileiras. São Paulo: Centro Brasileiro de Informações sobre Drogas Psicotrópicas (CEBRID), 1997.

HAWKINS, J.D.; CATALANO, R.F.; MILLER, J.Y. Risk and protestive factores for alcohol and other drug problems in adolescence and early adulthood: implications for substance abuse prevention. Psychol Bull, 1992; 112 (1): 64-5. Disponível em: <https://www.ncbi.nlm.nih.gov/pubmed/1529040>. Acesso em: 11 set. 2017

IBGE. Instituto Brasileiro de Geografia e Estatística. Guarulhos: Panorama, 2018. Disponível em: <https://cidades.ibge.gov.br/brasil/sp/guarulhos/panorama>. Acesso em: 05 mai. 2018.

INSTITUTO VISÃO PÚBLICA. Guarulhos: "em que ciclo da vida da cidade nos encontramos?" Guarulhos, $2015 . \quad$ Disponível em: <http://slideplayer.com.br/slide/2579943/>. Acesso em: 21 set. 2017.

MARTINS, Marco Antônio; PAGNAN, Rogério. Facção cria rede de tráfico no exterior. Folha de S. Paulo, São Paulo, 19 dez. 2011. Disponível em: <http://www1.folha.uol.com.br/fsp/cotidiano/15787-faccao-criou-rede-de-traficonoexterior.shtml>. Acesso em: 11 ago. 2017.

MOREIRA, André; VÓVIO, Claudia Lemos; DE MICHELI, Denise Prevenção ao consumo abusivo de drogas na escola: desafios e possibilidades para a atuação do educador. Educação e Pesquisa, v. 41, n. 1, p. 119-135, jan./mar. 2015, pp. 119-135. Universidade de São Paulo. São Paulo, Brasil.

MOREIRA, Marcelo Rasga. Nem soldados nem inocentes: jovens e tráfico de drogas no município do Rio de Janeiro. 2000. Dissertação (Mestrado em Ciências na área de Saúde Pública) - Escola Nacional de Saúde Pública, Rio de Janeiro, 2000.

MORIN, Edgar. Os sete saberes necessários à educação do futuro. 2. ed.rev. São Paulo: Cortez; Brasília: UNESCO, 2011.

NASCIMENTO, Marcelo Oliveira; DE MICHELI, Denise. Avaliação de diferentes modalidades de ações preventivas na redução do consumo de substancias psicotrópicas em estudantes 
no ambiente escolar: um estudo randomizado. RevistaCiência \& Saúde Coletiva, Rio de Janeiro, 20 (8): pp. 2499-2510, 2014.

OIT. Organização Internacional do Trabalho. Escritório Brasil. Crianças no narcotráfico: um diagnóstico rápido / Jaílson de Souza e Silva; André Urani (coordenadores); Organização Internacional do Trabalho; Ministério do Trabalho e Emprego. Brasília: OIT,2002.

OMS. Organização Mundial da Saúde. Transtornos devido ao uso de substancias. In: Organização Pan-Americana da Saúde, Organização Mundial da Saúde, organizadores. Saúde Mental: nova concepção, nova esperança. Relatório sobre a saúde no mundo. Brasília: Gráfica Brasil, 2003.

PASUCH, Clamartha; OLIVEIRA, Margareth da Silva. Levantamento sobre o uso de drogas por estudantes do ensino médio: Uma revisão sistemática. Cad. Ter. Ocup. UFSCar, São Carlos, v. 22, n. Suplemento Especial, p. 171-183, 2014.

PATTO, Maria Helena Souza. Introdução à psicologia escolar. 3 ed.São Paulo: Casa do Psicólogo, 1997.

PREFEITURA DE GUARULHOS. Economia de Guarulhos, 2018. Disponível em: <http://www.guarulhos.sp.gov.br/pagina/economia-de-guarulhos>. Acesso em: 05 mai. 2018.

REVISTA DE EDUCAÇÃO. Educação Patrimonial. Guarulhos: História, Cultura e Meio Ambiente. Ano 1, no 6, Nov/2012. Prefeitura de Guarulhos, Secretaria Municipal de Educação, 2012.

REVISTA MAROMOMI DIGITAL. Muitas cidades em uma só! Pensando nossa identidade.Guarulhos, AAPAH, v.1, n.1, p.1-30, set 2017.Disponível em: <http://aapah.org.br/revista maromomi digital/>. Acesso em: 21 ago. 2017.

ROCHA, Andréa Pires. Trajetórias de adolescentes apreendidos como "mulas" do transporte de drogas na região da fronteira (Paraná) Brasil - Paraguai:exploração de força de trabalho e criminalização da pobreza. 2012. 396 f. Tese(Doutorado em Serviço Social) - Faculdade de Ciências Humanas e Sociais, Universidade Estadual Paulista "Júlio de Mesquita Filho", Franca/SP, 2012.

RODRIGUES, Aroldo; ASSMAR, Eveline Maria Leal; JABLONSKY, Bernardo. Psicologia social.23 ed. Petrópolis: Vozes, 2005.

SANTOS, Juarez Cirino dos. A moderna teoria do fato punível. 4. ed. Curitiba: ICPC; Lumen Juris, 2005.

SILVA, Eroy Aparecida [et al.]. Drogas na adolescência: temores e reações dos pais. Psicologia: Teoria e Prática - 2006, 8 (1): 41-54.

SILVA, Marcos Sergio. No distrito onde mais se mata na Grande SP, delegacia fecha na sexta e só abre na segunda. Julho, 2017. Disponível em: $<$ https://noticias.uol.com.br/cotidiano/ultimas-noticias/2017/07/23/no-distrito-onde-maisse-mata-na-grande-sp-delegacia-fecha-na-sexta-e-so-abre-segunda.htm>. Acesso em: 02 ago. 2017.

TAPPARELLI, Gino e ALMEIDA, Andrija. Perfil dos adolescentes em conflito com a lei representados pela Promotoria de Justiça da Infância e da Adolescência em Salvador (2000-2003). 2005. Disponível em:<http://www.altrodiritto.unifi.it/ricerche/latina/almeida/>. Acesso em: 29 set. 2017. 
ZAMORA, Maria Helena. Adolescentes em Conflito com a Lei: Um breve Exame da Produção Recente em Psicologia. 2008.: 08 out. 2017. 